\title{
Marine Ecosystem Research at THE WedDELl SEA ICE EdGE: THE AMERIEZ PROGRAM
}

By Walker O. Smith, Jr., and David L. Garrison

$\mathrm{T}_{\mathrm{H}}$ HE EXPLORERS and naturalists who first visited Antarctica were struck by the large numbers of whales, seals and seabirds in such a harsh environment (summarized in Everson, 1977). Scientific expeditions in the twentieth century confirmed these observations, and also established that an even greater abundance of many different trophic levels occurred at the ice edge. Hart (1942) noted that phytoplankton were more abundant near the ice edge and suggested that there was a distinct ice-edge flora, and Marr (1962) noted that krill (Euphausia superba) were concentrated at the interface between pack ice and open water. Routh (1949) observed that seabirds were very abundant at the ice edge and suggested that the enhancement was due to the high plankton concentrations found in the area. All of these observations suggested that the ice edge played a potentially important role in the ecology of the southern ocean.

In the early 1980 s it became evident that the ice edge in Antarctic waters could have a major impact on the region's trophic dynamics as well as on the global cycles of carbon dioxide and other biogenic elements (e.g., Kukla and Gavin, 1981). Sea ice covers about 7\% of the total ocean surface and hence significantly reduces the amount of solar radiation absorbed at the surface, restricts the transfer of heat between the ocean and atmosphere, and influences global oceanic and atmospheric circulation (Zwalley et al., 1983a). Because the seasonal cycle of pack ice (ice which had formed the previous winter from surface cooling of seawater) in the Antarctic uncovers ca. $16 \times 10^{6} \mathrm{~km}^{2}$ each year, the effects of ice on the entire southern ocean

Editor's Note: Because of the unusual diversity and ongoing analyses of supporting data sets collected during AMERIEZ, we make an exception to the magazine's policy not to accept references to "unpublished data" or "personal communication." More information concerning data sets or analyses so referenced in this paper can be obtained from sources identified in Table 1.

Walker O. Smith, Jr., Botany Department and Graduate Program in Ecology, University of Tennessee. Knoxville, TN 37996; David L. Garrison, Institute of Marine Sciences, University of California, Santa Cruz, CA 95064 are substantial. Although a number of previous studies had sampled at or near the ice edge, no mesoscale study had investigated the coupling between the physical processes within the marginal ice zone (the ecotone between consolidated ice and ice-free waters which are not impacted by ice) and the rates of primary productivity, or the interactions among phytoplankton, zooplankton, krill, nekton, birds and mammals at an ice edge. In 1981 a National Academy of Sciences report emphasized the critical need for research in biological oceanography in the Antarctic because of the great intrinsic interest in the region and its renewable and nonrenewable resources, and in particular research directed toward understanding the dynamics of the Antarctic ice edge and its role in the region's trophic dynamics (NRC, 1981). The AMERIEZ (Antarctic Marine Ecosystem Research at the Ice Edge Zone) Program was developed in response to this need. The AMERIEZ study has investigated two majorquestions: - What are the mechanisms which result in enhanced productivity at all trophic levels within the marginal ice zone?

- Is the ice edge an ecological interface between two distinct biological communities, one associated with the open ocean and one with the pack ice, and what are the dynamics of these seasonal communities?

To address these questions, we measured the distributions of fauna and flora and, whenever possible, their rate processes, over a wide range of conditions during different seasons within the marginal ice zone. Because of the nature of the program's hypotheses, a multidisciplinary program was designed to sample seasonally within the marginal ice zone. A list of the specialties addressed and the program's Principal Investigators is presented in Table 1 .

The marginal ice zone of the Weddell Sea was chosen as the program's study site for both scientific and logistic reasons. The Weddell Sea is of general interest because of the large role it plays in thermohaline circulation, deep water formation and oceanic biogeochemical cycles. Based on satellite images of ice conditions from previous years (Zwally etal., 1983a, b), the presence and seasonal dynamics of ice in the Weddell Sea were also more predictable than in many other areas, and the region afforded a study site which 
was in deep water, easily accessible (relative to other potential Antarctic sites), and removed from features generated by complicated bottom topography. As judged from previous ice-cover data, it was expected that the ice pack would be rapidly retreating during austral spring, and we anticipated that these conditions would initiate an ice-edge phytoplankton bloom. In 1983 a cruise to the ice edge involving two ships was completed to determine the distributions and rate processes within the food web during this season (Fig. 1, p. 24). In 1986 a two-ship cruise to the ice edge was conducted to investigate late summer/early autumn conditions (Fig. 1). The study area had recently been characterized by little or no ice ablation, and in some locations the ice was beginning to advance. Finally, in 1988 an experiment was completed during austral winter, the time of maximum ice extent (Fig. 1). This cruise had two legs; the first concentrated on pack-ice processes, and the second emphasized water-column processes. Although a complete investigation of the seasonal dynamics of the ice edge has not yet been completed, the results from AMERIEZ have clearly elucidated a number of mechanisms by which productivity of all trophic levels is enhanced at the ice edge, as well as the processes which structure communities within the marginal ice zone. In addition, our results have also raised many new questions about material and energy flow in the southern ocean.

\section{Primary Productivity in the Weddell Sea}

\section{Marginal Ice Zone}

Solar radiation is the major factor controlling primary productivity in high latitude systems (Sakshaug and Holm-Hansen. 1984). In the southern ocean the irradiance field experienced by phytoplankton is a function not only of the seasonal solar radiation cycle, but also of the depth of the mixed layer and the presence or absence of sea ice. The growth/decay cycle of sea ice is driven both directly and indirectly by the seasonal variations in solar radiation and results from a complex relationship within the atmosphere-ocean-ice system. The ice pack begins its retreat in September, and the maximum rate of retreat occurs in November to December (Zwally et al., 1983a): however, significant interannual variations in the extent of sea ice cover and the timing of its retreat occur both within the entire southernocean and within its various sectors. Variations in ice extent were large in the 1970s (the maximum extent ranged from 17.2 to $20.6 \times 10^{6} \mathrm{~km}^{2}$ in 1977 and 1973, respectively; Zwalley et al., 1983b), but were relatively small in the 1980s (from 1979-1985 the range of maximum ice extent was from 19.8 to $20.2 \mathrm{x}$ $10^{6} \mathrm{~km}^{2}$; Smith et al., 1988). Therefore, it appears that the period that AMERIEZ sampled was one which had relatively predictable ice cover and retreat.

Hydrographic observations made during AMERIEZ suggest that enhanced stratification induced by melting ice is an important factor in promoting the accumulation of high standing stocks of phytoplankton near the ice edge. This finding directly addressed the first question posed by AMERIEZ: the mechanism(s) of the enhancement of productivity. During austral spring the density structure was heterogeneous, with pockets of

\section{Physical Oceanography \\ Dr. Arnold Gordon \\ Lamont-Doherty Geological Observatory \\ Columbia University \\ Palisades. NY 10964 \\ Dr. Bruce Huber \\ Lamont-Doherty Geological Observatory \\ Columbia University \\ Palisades. NY 10964 \\ Dr. Robin Muench \\ SAIC \\ 13400B Northup Way, Suite 36 \\ Bellevue. WA 98005 \\ Dr. D.M. Husby \\ Pactic Environmental Group \\ NMFS/NOAA \\ Monterey. CA 93940}

\section{Remote Sensing}

Dr. Joey Comiso

Laboratory for Oceans

Code 671

NASA Goddard Space Flight Center

Greenbelt. MD 20771

\section{Nutrients}

Dr. Louis I. Gordon

College of Oceanography

Oregon State University

Corvallis, OR 97331

\section{Stable Isotope Distribution \\ Dr. Greg Rau \\ MS 239-4 \\ NASA Ames Research Center \\ Moffett Field, CA 94035}

\section{Bacterial Biomass and Productivity \\ Dr. Cornelius Sullivan \\ Dept. of Biological Sciences \\ University of Southern California \\ Marine Biology Research Section \\ Unuversity Park \\ Los Angeles, CA 90089-0371}

\section{Phytoplankton Biomass \\ and Productivity \\ Dr. Walker O. Smith. Jr. \\ Graduate Program in Ecology \\ 108 Hoskins Library \\ University of Tennessee \\ Knoxville, TN 37996 \\ Dr. David Nelson \\ College of Oceanography \\ Oregon State University \\ Corvallis. OR 97331}

\section{Phytoplankton Taxonomy}

Dr. Greta Fryxel]

Department of Oceanography

Texas A\&M University

College Station, TX 77843-3146
Euphausiid Distribution

Dr. Michael Macaulay

N.W. Fisheries Center

NOAA/NMSF

RACE

Seattle. WA 98195

Dr. E. Brinton

Scripps Institution of Oceanography La Jolla, CA 92093

Dr. Mark Huntley

La Jolla. CA $92(193$

Dr. Jean Stepien

Lamont-Doherty Geological Observatory

Columbia University

Palisades. NY 10964

\section{Ice Biota and \\ Microzooplankton \\ Dr. David Garrison \\ University of California \\ Santa Cruz, CA 95064 \\ Dr. Marica Gowing \\ University of California \\ Santa Cruz. CA 95064 \\ Dr. John Heinbokel \\ Chesapeake Bay Institute \\ 4800 Atwell Road \\ Shady Side, MD 20764}

Institute of Coastal \& Marne Sciences

Institute of Coastal \& Marine Sciences

\section{Micronekton and \\ Macrozooplankton \\ Dr. Jose Torres \\ Dept, of Marine Science \\ University of South Florida \\ 140 Seventh Ave. South \\ St. Petersburg, FL 33701 \\ Dr. Thomas L. Hopkins \\ Dept. of Marine Science \\ University of Florida \\ St. Petersburg, FL 33701}

\section{Marine Birds \\ Dr. David G. Ainley \\ Point Reyes Bird Observatory \\ 4990 Shoreline Hwy. \\ Stinson Beach. CA 94970 \\ Dr. William Fraser \\ Point Reyes Bird Observatory \\ 4990 Shoreline Hwy. \\ Stinson Beach. CA 94970}

\section{Marine Mammals}

Dr. John L. Bengtson

National Marine Mammal Laboratory

7600 Sandy Point Way, NE

Seattle, WA 98115

Dr. Albert Eriksen

232 Fisheries Center

University of Washington

Seattle, WA 98195
Scripps Institution of Oceanography

Table I: AMERIEZ scientific projects and Principal Investigators. All data referred to in text as "personal communication" or "unpublished data" can be obtained directly from the listed investigator. 


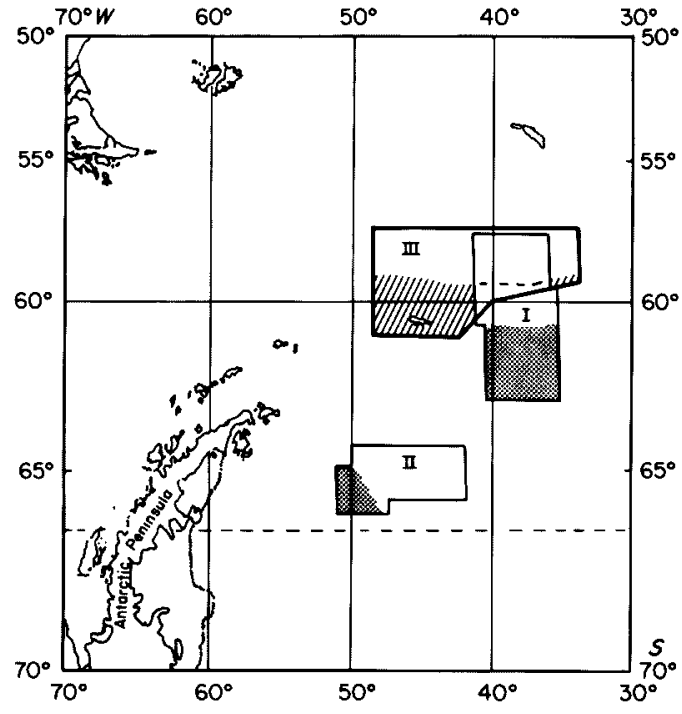

Fig. 1: Location of the three cruises to the Weddell Sea ice edge: austral spring (I: November 10 through December 2, 1983), the austral autumn (II: March 727. 1986), and the austral winter (III: June 9 through August 13, 1988). Location of ice shown by shading with either stiples or hatches.

low-salinity water creating regions of enhanced stratification (Fig. 2a; Nelson et al., 1987). In contrast, the distribution of density at the stagnant or advancing ice edge sampled in autumn 1986 was uniform, with the pycnocline consistently occurring between 35 and 50 m (Fig. 2b; Nelson et al., 1989). Although the ice edge may have shown little spatial movement during this period, melt-water was still being produced because ice is always melting at the ice edge, regardless of season. During the winter a weakly stratified system was observed, with mixed layers often more than 125 $\mathrm{m}$ deep (Fig. 2c; Husby et al., 1989). These observations indicate that melting ice creates significant vertical stratification that persists until it is disrupted by the vertical thermohaline circulation generated during ice (and brine) production or vertical mixing induced by wind and/or ice movement.

The relationship between phytoplankton biomass and hydrographic features varied seasonally. During spring the distribution of pigments was correlated with that of density (Fig. 3a; Nelson et al., 1987; Sullivan et al., 1988), a relationshipexpected from previousstudies (Smith and Nelson, 1985). In autumn, however, large spatial variations in pigment levels were observed that could not be associated with a stratified density structure alone (Fig. 3b; Nelson et al., 1989; Comiso et al., 1990) but instead were related to the length of time the region had been ice-free. Although the AMERIEZ study region had only moderate chlorophyll concentrations (average surface values were ca. $0.7 \mu \mathrm{g} \mathrm{I}^{-1}$ ), much higher pigment levels (more than $4 \mu \mathrm{g} \mathrm{l}^{-1}$ ) were observed farther south along the ice edge (Fig. 3b; Comiso etal., 1990). The occurrence of autumn ice-edge blooms at some locations results from growth in stratified waters which had been ice-free long enough to permit
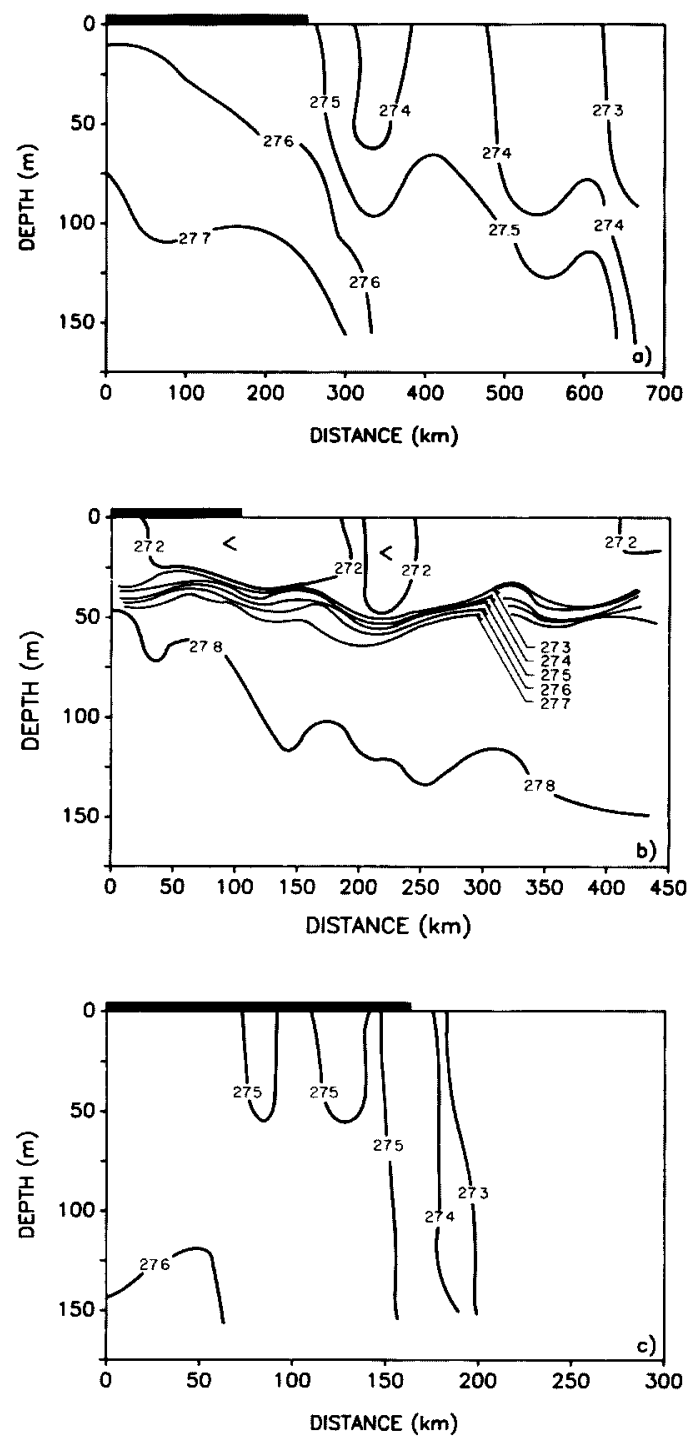

Fig. 2: The density distribution found along a transect perpendicular to the ice during ( $a$, top) austral spring (Fig. 3 b from Nelson et al., 1987), (b, middle) austral autumn (Fig. 2e from Nelson et al., 1989), and (c) austral winter (modified from Husby et al., 1989). The solid horizontal bar represents the approximate distribution of ice; all sections taken normal to the ice edge.

the accumulation of phytoplankton. Therefore, the duration of ice cover controls the irradiance environment of phytoplankton and is a critical mechanism regulating primary productivity at the ice edge. In winter chlorophyll- $a$ concentrations were low and relatively uniform (Fig. 3c, p. 26). This was not unexpected given the depth of the mixed layer, the low surface irradiances, high solar angles and short photoperiods. Despite the variability among seasons, the ice edge always exhibited enhanced concentrations of chlorophyll (as well as particulate carbon, biogenic silica and particulate nitrogen) relative to regions under the ice or spatially removed from the ice edge.

Primary productivity also was elevated near the ice edge in all seasons. This primarily is due to the en- 
Fig. 3: The chlorophyll distribution found at the ice edge during ( $a$, top) the austral spring (after Sullivan et al., 1988) and (b) the austral autumn (from Comiso et al., 1990). The spring and autumn Coastal Zone Color Scanner satellite images show near-surface maps of pigment concentrations from less than $0.1 \mu \mathrm{g}$ $l^{-1}$ (blue) to more than $4.0 \mathrm{\mu g} \mathrm{l}^{-1}$ (orange). Figure $3 \mathrm{con}$ p. 26.

hanced irradiance field experienced by phytoplankton after stratification was created, since the ice edge is always a site of some stability, although its strength varies seasonally. Productivity for the spring, autumn and winter periods averaged 489, 126 and $32 \mathrm{mg}$ $\mathrm{C} \mathrm{m}^{-2} \mathrm{~d}^{-1}$, respectively (Smith and Nelson, 1990; Smith, unpubl. data. Note: All unpublished data referred to in this papercan be obtained directly from the appropriate Principal Investigator; see Table 1). Much of this production, as determined by direct ${ }^{15} \mathrm{~N}$-uptake studies, was based on nitrate (Smith and Nelson, 1990). Mean f-ratios (the ratio of nitrate uptake to the sum of nitrate plus ammonium uptake; uptake of dissolved organic nitrogen was not measured) for spring and autumn were 0.53 and 0.72 , implying that most of the production in the marginal ice zone was new production and available for export to sub-euphotic depths.

\section{Secondary Producers}

The enhanced phytoplankton biomass and productivity in the marginal ice zone was expressed at several levels in the pelagic food web. Bacterio-plankton biomass and productivity were spatially correlated with algal biomass and production, and bacterial productivity (as estimated by tritiated thymidine uptake) ranged from $1-32 \%$ and $18-151 \%$ of primary productivity in the spring and autumn studies, respectively (Sullivan et al., 1990; Cota et al., 1990). Microzooplankton (heterotrophic flagellates and ciliated protozoa) biomass also followed gradients in phyto- and bacterio-plankton biomass (Garrison and Buck, 1989a; Fig. 4, p. 27). Similar relationships were observed during the winter cruise (Garrison, pers. comm.). Stable isotope $\left({ }^{15} \mathrm{~N}\right.$ in particulate matter) analyses of 1986 samples suggest that substantial rates of recycling may have been occurring in autumn (Rau, unpubl. data), which is consistent with the trends in bacterial productivity and bacterial and microzooplankton biomass. The spatial correlation between autotrophic and heterotrophic microplankton suggest that the increased abundances of secondary producers was a direct result of the increased phytoplankton productivity.

Biomass of zooplankton was roughly equivalent in open water, at the ice edge, and under the ice during autumn and winter (Hopkins and Torres, 1988, unpubl. data; no data are available for spring). The observed biomass ( 1.1 to $1.3 \mathrm{~g}$ dry weight $\mathrm{m}^{-2}$ from 0 to $1000 \mathrm{~m}$ ) is similar to that found in oligotrophic oceanic regimes. Although the presence of ice did not influence the horizontal distribution of zooplankton, it did modify the vertical distribution. In general, the maximum in
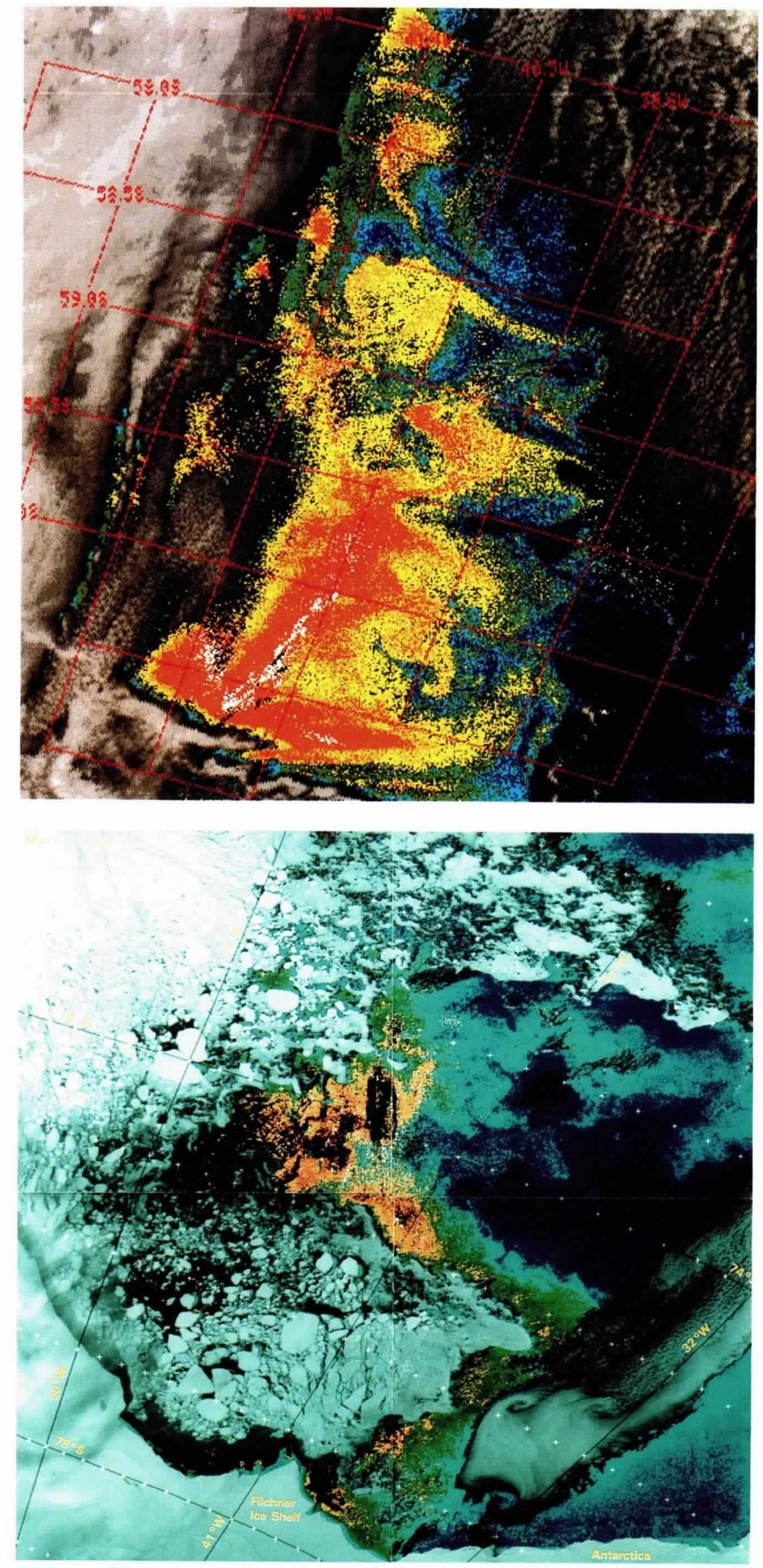


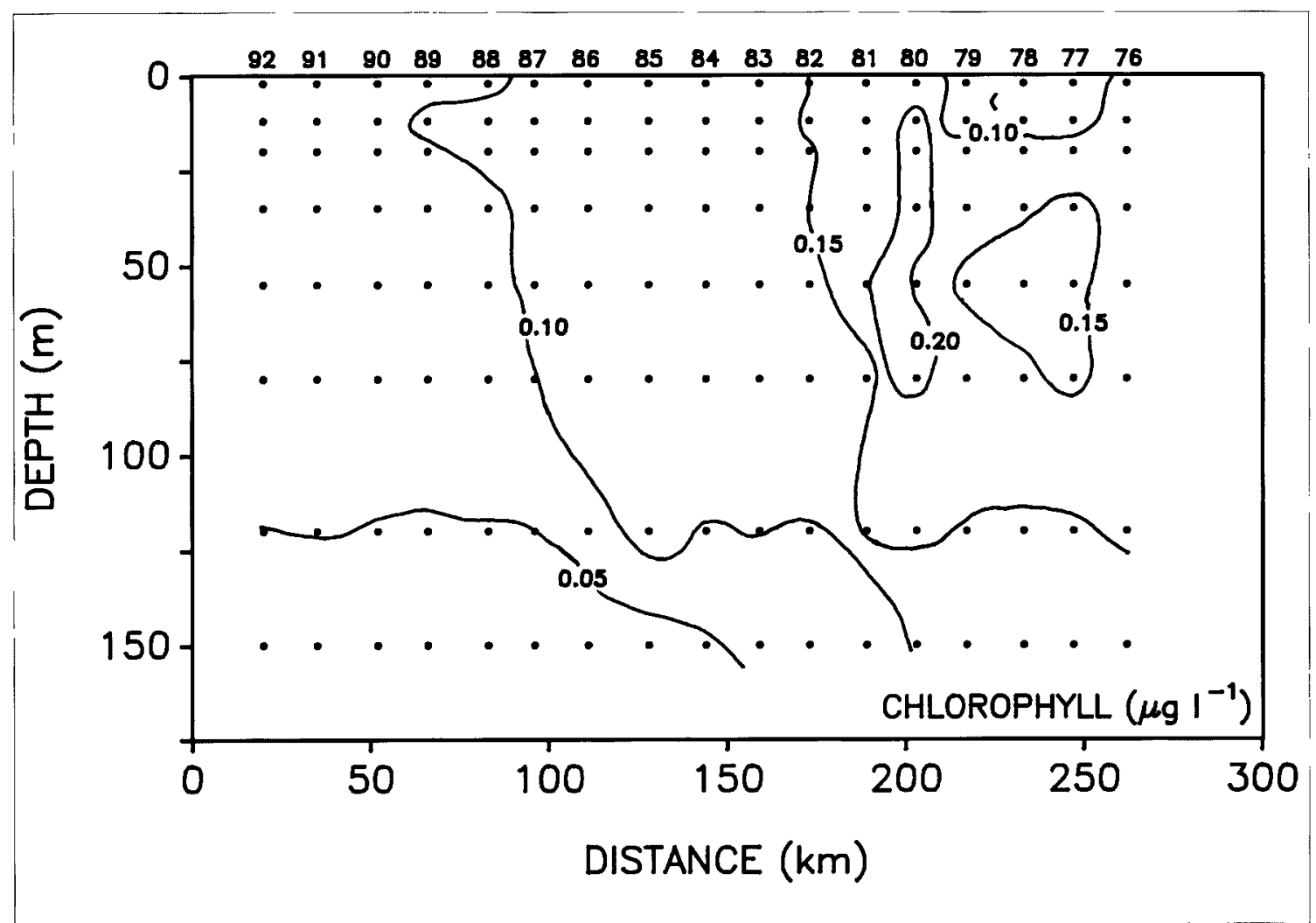

Fig. 3c: The chlorophyll distribution found at the ice edge during the austral winter (Smith, pers. comm.). Data collected along a vertical transect at $40 \mathrm{~W}$ from $57^{\circ} 40.3^{\prime}$ to $59^{\circ} 46.3^{\prime} \mathrm{S}$.

zooplankton biomass distribution occurred deeper in the water column under the ice than in open water. Finally, feeding activity was greatly reduced during winter, particularly among herbivorous zooplankton.

The relationship of the distribution of large pelagic consumers to elevated plankton biomass in the marginal ice zone varied seasonally. In spring 1983 the concentrations and distributions of Euphausia superba, a potential key link in the Antarctic food web, were similar under ice and in open water, with biomass in the surface layer (ca. $100 \mathrm{~m}$ as determined by acoustic methods) ranging from 1-100 g wet weight $\mathrm{m}^{-2}$ (Daly and Macaulay, 1988), and noclear correlation between the ice-edge location and krill biomass was observed. Plankton tows and seabird stomach analyses showed that the size/age composition of $E$. superba, however, did vary geographically. Younger (and faster growing) krill were concentrated in the marginal ice zone (Ainley et al., 1988; Daly and Macaulay, 1988). Salps were extremely abundant in 1983 in open water but were virtually absent under the pack ice, presumably due to the lack of phytoplankton under the ice. In autumn 1986 , krill biomass as determined by acoustic methods was more than an order of magnitude lower than in 1983, and again no relationship of krill biomass to the ice-edge position was noted (Macaulay, unpubl. data). Mid-water trawls did not detect a difference between the two years as large as that found by acoustic means. although the euphausiid biomass was observed to decrease in the $0-200 \mathrm{~m}$ layer from 0.8 to $0.6 \mathrm{~g}$ dry weight $\mathrm{m}^{-2}$ (Lancraft et al., 1989). Salps, also less abundant than in spring, were found in open water and under the pack ice. In contrast to spring and autumn, winter krill biomass was maximal near the ice edge (Macaulay, unpubl. data). During all seasons $E$. superba were concentrated in the upper mixed layer. Other macrozooplankton and micronekton occurred (coelenterates, fish), but euphausiids were this group's largest single component. Based on their biomass, fish were the most important predator of krill in the region (Lancraft et al., 1989).

Higher Trophic Levels

Higher trophic levels are generally conspicuous by their large numbers at the ice-edge and often include minke whales (Balaenoptera acutorostrata), crabeater and leopard seals (Lobodon carcinophagus and Hydrurga leptonyx), emperor and Adélie penguins (Aptenodytes forsteri and Pygoscelis adeliae), snow and Antarctic petrels (Pagodroma nivea and Thalassoica antarctica), and the southern polar skua (Catharacta maccormicki) (Ainley and DeMaster, 1990). Studies of apex predators have clearly shown that the ice edge is the delimiter of two major communities, one associated with the pack ice and one associated with open water removed from the ice edge. For example, seabird biomass was high near the ice edge during all seasons sampled, with the seasonal maximum during autumn and minimum during winter (Fig. 5, p. 28). This suggests that the physical presence of ice is the dominant organizing feature for seabird communities in the 
southern ocean. Differences in prey size and composition also occur among these seabird assemblages, presumably the result of differences in relative availability of these prey, which in turn was strongly correlated with the presence of ice (Ainley et al.. 1988). Many of the seals and whales also appear to occupy specific habitats with the marginal ice zone and alter their distribution with season (Ainley and Fraser, pers. comm.). Thus, an original AMERIEZ hypothesis has been verified; namely, that the ice edge is indeed a critical ecological interface in the southern ocean.

It has been suggested that the Antarctic food web is not a simple chain from diatoms to krill to higher trophic levels (e.g., Everson, 1977), and the AMERIEZ findings provide additional evidence of the complexity of the Antarctic food web. The presence or absence of certain micronekton in the diet of seabirds was strongly correlated with pack ice (Ainley et al., 1986, 1988). In all seasons krill was an important item in seabirds' diets, especially in open water immediately adjacent to the ice edge, but myctophid fishes (especially Electrona antarctica) were also a common food item. Squid were also commonly ingested by seabirds as well. These findings emphasize that some higher trophic levels within the marginal ice zone do not rely solely on krill but utilize other prey to a significant degree. During winter, seabirds may ignore krill and feed on the energetically more valuable fishes (Ainley, pers. comm.).

\section{The Sea Ice Community}

Seasonal sea ice greatly attenuates solar radiation and virtually eliminates phytoplankton production in the underlying water column. However, the sea ice may be an important site of production because it is often a habitat in which various organisms (e.g., algae, bacteria, larval and juvenile invertebrates) occur and achieve large standing stocks. Chlorophyll- $a$ concentrations in sea ice are usually one or two orders of magnitude higher than those in the underlying water (Garrison et al., 1986; Garrison and Buck, 1989b). Maximum chlorophyll concentrations in pack ice appear to develop during the early spring (OctoberNovember), reaching more than $400 \mu \mathrm{g}$ chlorophyll- $a$ $\mathrm{I}^{-1}$ of ice in a $20-30 \mathrm{~cm}$ layer below the snow-ice interface (Garrison and Buck, 1989b). For comparison. integrated chlorophyll concentrations were approximately 50 and $225 \mathrm{mg} \mathrm{m}^{-2}$ in the euphotic zone of upwelling systems and an ice-edge bloom. respectively (Barber and Smith, 1981; Smith and Nelson, 1985). In pack ice, ice algae also are found throughout ice floes as internal populations; these are characterized by lower chlorophyll- $a$ concentrations than the surface assemblages and show little seasonal patterns in biomass. Bacteria and heterotrophic protozoa also appear to show similar degrees of concentration in sea ice (Garrison and Buck, 1989b).

Diatoms are numerically the dominant microbes within sea ice, but bacteria, autotrophic flagellates and a variety of heterotrophic protozoa and larval metazoans are also abundant (Garrison, 1990). The presence of resting stages of various forms of algae suggest specific adaptations for survival in sea ice, but the life
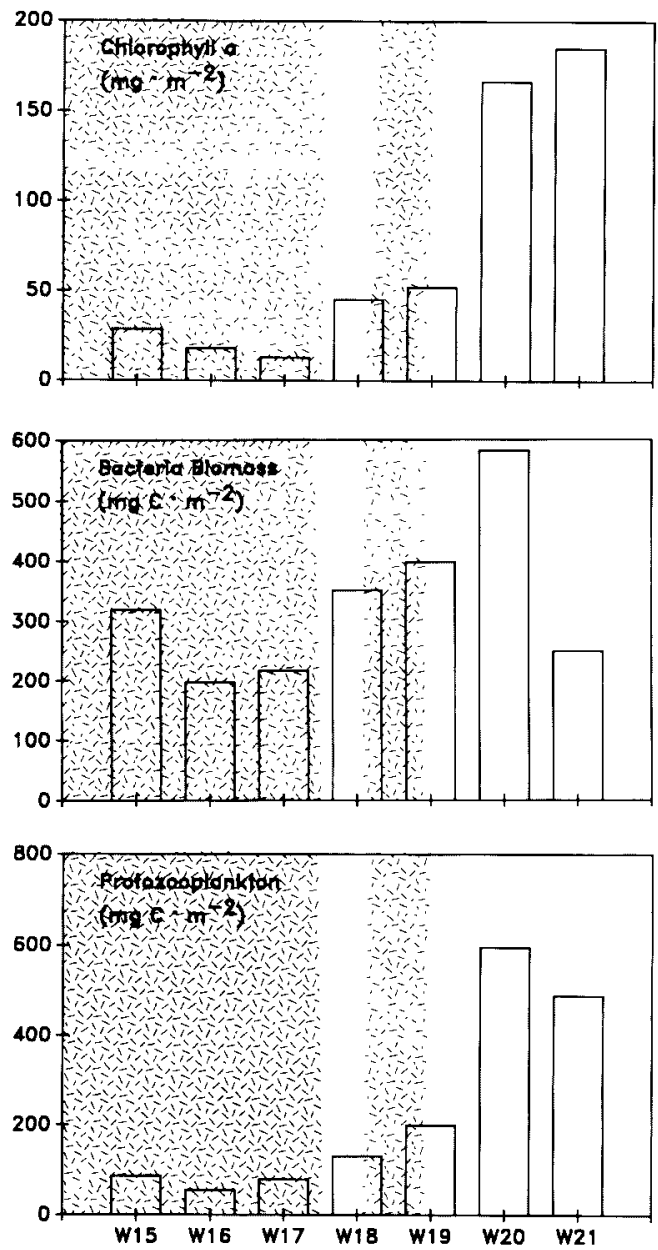

Fig. 4: Integrated biomass of phytoplankton (chlorophyll-a, upper panel), bacteria (middle panel) and protozooplankton (lower panel) in the upper $100 \mathrm{~m}$ within a series of stations along a transect across the marginal ice zone during austral spring (from Garrison and Buck, 1989a). Stipled area indicates ice cover.

cycles of many of the organisms in ice are still poorly known. The abundances of these organisms and the trophic diversity suggests that the ice community supports an active microbial food web, although only bacterial and algal growth rates have been measured (Sullivan, unpubl. data). However, the measurement of ice-related growth and production is difficult because nearly all methodologies involve the disruption of the ice environment. and the rates obtained therefore have a large degree of uncertainty. Elevated ratios of carbon:chlorophyll ( $>500)$, carbon:nitrogen $(>10)$ and C:ATP (carbon:adenosine triphosphate) ( $>250)$, as well as direct microscopic observations, indicate that ice is a site of grazing and detrital production and accumulation (Buck et al., 1990). With seasonal melting, the ice-bound particulate load becomes progressively more available to pelagic consumers. Larval and juvenile krill are commonly found associated with ice during all seasons (Daly and Macaulay, 1988), and it is now clear that the pack ice provides a major source of 


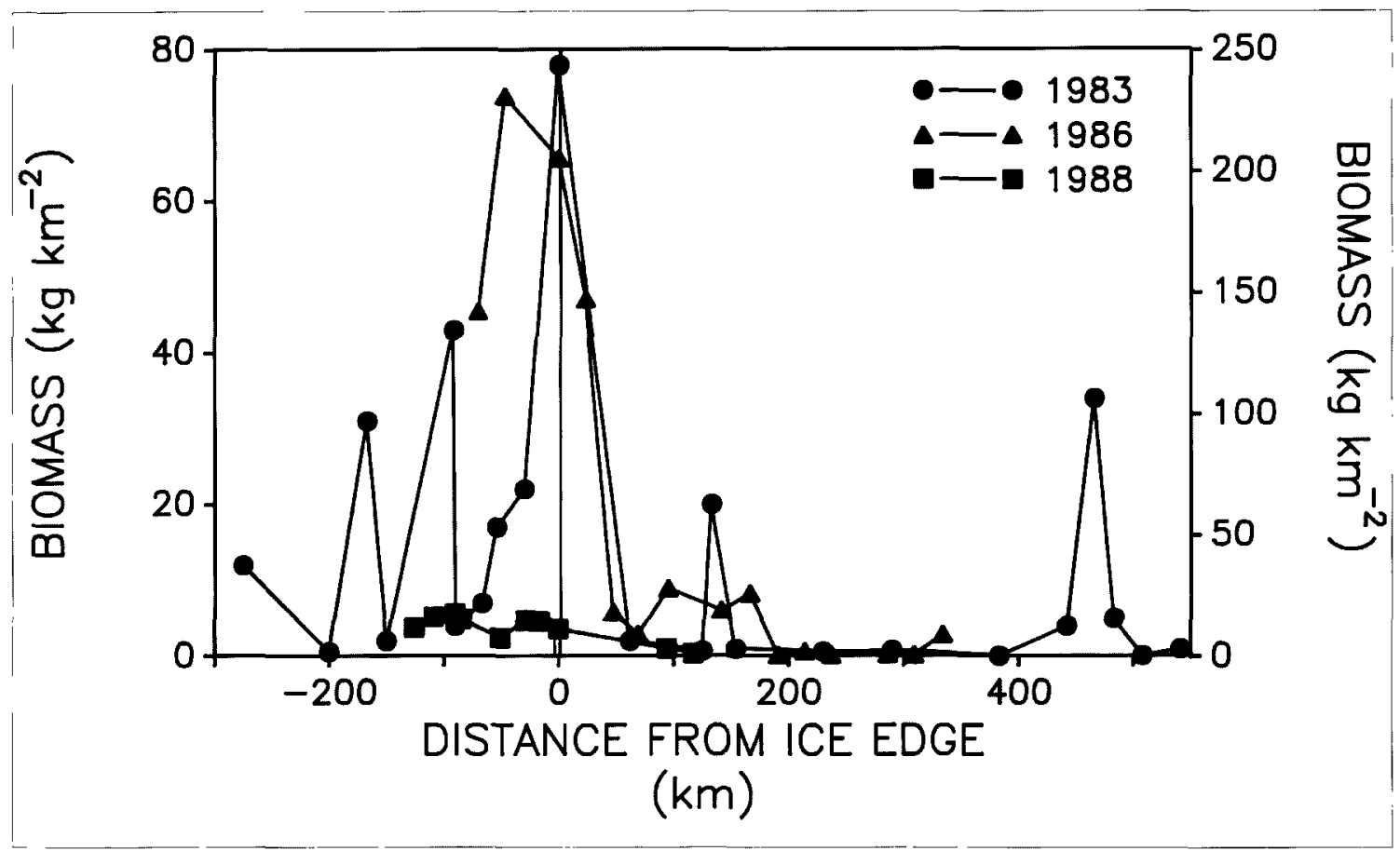

Fig.5:The distribution of seabird biomass in relation to the ice edge during the three seasons sampled (from Fraser and Ainley, 1986; Ainley and Fraser, unpubl. data). 1983 and 1988 biomass data use left-hand scale; 1986 data use right-hand scale.

food for sub-adult Euphausia superba (Daly and Macaulay, 1988), which is also true for other euphausiids, amphipods and copepods (Garrison, 1990). These consumers in turn provide abundant food for higher trophic levels such as squid, fish and birds.

Sea ice is a temporary habitat, and the ice biota and any accumulations of detritus are eventually released into the water column upon melting. A marked similarity among diatom assemblages in ice and in the water column implies that ice communities seed developing ice-edge blooms (Garrison et al., 1987); a similar seeding of water column bacteria and heterotrophic protozoa has also been suggested (Sullivan $e t$ al., 1990). Accumulations of fecal material and other detritus released from ice may comprise a small but seasonally significant flux of biogenic material to deep water (Buck et al., 1990).

The Ice Edge: Present Knowledge and Future Research Directions

As a result of the AMERIEZ studies, it is clear that the ice edge is quantitatively important as a source of biogenic production at all times of the year. The critical mechanisms responsible for the enhancement of phytoplankton biomass at the ice edge appear to be vertical stratification of the water column and the length of time the area had been ice-free. The production has two components, the first associated with the ice community and the second with the ice-edge phytoplankton bloom. The ice-associated production is important because it is a highly concentrated resource and is available throughout the winter and early spring when phytoplankton production is negligible (the ice edge nearly always receives some irradiance because it is above the Antarctic Circle, even at the time of the austral winter solstice; Zwally et al., 1983a). Because the ice production is available in winter and spring, it is a critical food source for larval and juvenile euphausiids. The phytoplankton production at the ice edge, which is consistently higher than in the open waters removed from ice or in areas of heavy pack ice, is also a concentrated and predictable resource for pelagic consumers. Moreover, direct measurements suggest that the production is based on nitrate, and hence the ice edge may be even more significant as a source of new production than is the open ocean, where production has been shown previously to rely more on ammonium (e.g., Koike et al., 1986). Finally, given the intensity of production, the biomass observed, the icerelated productivity and the areal extent involved. the marginal ice zone becomes the single most quantitatively important source of biogenic material to the entire southern ocean.

It is also apparent that the pack ice strongly influences the distribution and feeding behavior of deepwater pelagic organisms in the region. The physical structure of the sea ice provides a habitat for the growth of microbial assemblages, which are then used by grazing organisms. The larger pelagic consumers in turn provide a concentrated source of prey for apex predators. The ice also influences the vertical distribution of pelagic organisms in the Antarctic. For example, a number of mesopelagic organisms have been found at the surface in the pack ice, apparently in response to food availability (Ainley et al., 1986). Therefore, the presence of ice per se is responsible for much of the complexity in structure and organization within the marginal ice zone, and certainly the iceinfluenced portion of the southern ocean. Similarly, the 
ice edge clearly is an important ecological interface which separates two distinct communities.

A number of questions remain to be addressed by future research within marginal ice zones of the Antarctic. There presently is no consensus on the contribution of ice-edge phytoplankton blooms to the vertical flux of biogenic matter, nor is it clear to what extent the ice biota contribute to this process. The quantitative role of the sea ice biota in the trophic dynamics of the food web at the ice edge also remains unclear, and the in situ measurement of realistic production and consumption rates within the sea ice community remains a challenging problem. The role of the marginal ice zone in maintaining stocks of krill also needs to be explored. Finally, the mechanisms by which ice influences the distribution, activity and organization of a wide variety of organisms will offer insight into the structure and function of southern ocean communities, particularly the temporal relationship between organisms with wide-ranging generation times and variable resource availability. Undoubtedly research within Antarctic marginal ice zones will continue to clarify the ecological role of these regions within the entire southern ocean.

\section{References}

Ainley, D.G., W.R.Fraser, C.W.Sullivan, J.J.Torres, T.L.Hopkins and W.O. Smith, Jr., 1986: Antarctic mesopelagic micronekton: Evidence from seabirds that pack ice affects community structure. Science, 232, 847-849. and K.L. Daly, 1988: Affects of pack ice on the composition of micronektonic communities in the Weddell Sea. In: Antarctic Ocean and Resources Variability. D.Sahrhage, ed., Springer-Verlag, Berlin. 140-146. and D.P. DeMaster, 1990: The upper trophic levels in polar marine ecosystems. In: Polar Oceanography, Part B. W.O. Smith, Jr., ed., Academic Press, San Diego, 599630.

Barber, R.T. and R.L. Smith, 1981: Coastal upwelling ecosystems. In: Analysis of Marine Ecosystems. A. Longhurst, ed., Academic Press, New York, 31-68.

Buck, D.R., P. Bolt and D.L. Garrison, 1990: Phagotrophy and fecal pellet production by an athecate dinoflagellate in Antarctic sea ice. Mar. Ecol. Prog. Ser., 160, 75-84.

Comiso, J.C., N.G. Maynard, W.O. Smith, Jr. and C.W. Sullivan. 1990: Satellite ocean color studies of Antarctic ice edges in summer/autumn. J. Geophys. Res., 95(9), 481-489, 496.

Cota. G.F.. S. Kottmeier, D. Robinson, W.O. Smith, Jr., and C. Sullivan, 1990: Bacterioplankton in the marginal ice zone of the Weddell Sea: biomass, production and metabolic activities during austral autumn. Deep-Sea Res., 37, (in press).

Daly, K.L. and M.C. Macaulay, 1988: Abundance and distribution of krill in the ice edge zone of the Weddell Sea, austral spring 1983. Deep-Sea Res., 35. 21-41.

Everson, I., 1977: The Living Resources of the Southern Ocean. FAO, Rome, 133 pp.

Fraser, W.R, and D.G. Ainley, 1986: Ice edges and seabird occurrence in Antarctica. BioScience, 36, 258-263.

Garrison, D.L., 1990: Antarctic sea ice biota. Amer. Zool.. 30, (in press).

, C. Sullivan and S. Ackley, 1986: Sea ice microbial communities in Antarctica. BioScience, 36, 243-250.

, K.R. Buck,and G. Fryxell, 1987: Algal assemblages in Antarctic pack ice and in ice-edge plankton.J.Phycol., 23, 564-572. and 1989a: Protozooplankton in the Weddell
Sea, Antarctica: abundance and distribution in the iceedge zone. Polar Biol., 9, 341-351.

and 1989b: The biota of Antarctic pack ice in the Weddell Sea and Antarctic peninsula regions. Polar Biol., 10, 211-219.

Hart. T.J., 1942: Phytoplankton periodicity in Antarctic surface waters, Discovery Rep., 21, 261-356.

Hopkins, T.L. and J.J. Torres, 1988: The zooplankton community in the vicinity of the ice edge, western Weddell Sea, March 1986. Polar Biol., 9. 79-87.

Husby, D.M., R.D. Muench and J. Gunn, 1989: Oceanographic observations in the Scotia Sea marginal ice zone JuneAugust 1988. NOAA-TM-NMFS-SWFC-127.

Koike. I., O. Holm-Hansen and D.C. Biggs, 1986: Inorganic nitrogen metabolism by Antarctic phytoplankton with special reference to ammonium cycling. Mar. Ecol. Prog. Ser., 30, 105-116.

Kukla. G. and J. Gavin, 1981: Summer ice and carbon dioxide. Science. 214, 497-503.

Lancraft, T.M. J.J. Torres and T.L. Hopkins, 1989: Micronekton and macrozooplankton in the open waters near Antarctic ice edge zones (AMERIEZ 1983 and 1986). Polar Biol..9. 225-233.

Marr, J.W.S., 1962: The natural history and geography of the Antarctic krill (Euphausia superba Dana). Discovery Rep.. 32, 33-464.

NRC. National Research Council, 1981: An Evaluation of Antarctic Marine Ecosystem Research. National Academy Press, Washington, D.C., 99 pp.

Nelson, D.M., W.O. Smith, Jr.. L.I. Gordon and B.A. Huber. 1987 : Spring distributions of density, nutrients, and phytoplankton biomass in the ice-edge zone of the Weddell-Scotia Sea. $J$. Geophys. Res.. 92.7181- 7190.

, R. Muench. L.I. Gordon. C.W. Sullivan and D.M Husby, 1989: Particulate matter and nutrient distributions in the ice-edge zone of the Weddell Sea: relationship to hydrography during late summer.Deep-Sea Res., 36, 191-209.

Routh, M.. 1949: Omithological observations in the Antarctic seas. Ibis, 91, 577-606.

Sakshaug, E. and O. Holm-Hansen, 1984: Factors governing pelagic production in polar oceans. In: Marine Phytoplankton and Productivity. O. Holm-Hansen. L. Bolis and R. Giles, eds., Springer-Verlag, Berlin, 1-18.

Smith, W.O. and D.M. Nelson, 1985: Phytoplankton bloom produced by a receding ice edge in the Ross Sea: spatial coherence with the density field. Science, 227, 163-166.

Smith. W.O., Jr., N.K. Keene and J.C. Comiso, 1988: Interannual variability in estimated primary productivity of the Antarctic marginal ice zone. In: Antarctic Ocean and Resources Variability. D. Sahrhage, ed., Springer-Verlag, Berlin, 131-139.

and D.M. Nelson, 1990: Phytoplankton growth and new production in the Weddell Sea marginal ice zone during austral spring and autumn. Limnol. Oceanogr., 35, (in press).

Sullivan, C.W., C.R. McClain. J.C. Comiso and W.O. Smith, Jr., 1988: Phytoplankton standing crops within an Antarctic ice edge assessed by satellite remote sensing. J. Geophys. Res., 93, 12,487-12.498.

G.F. Cota, D.W. Krempin and W.O. Smith, Jr., 1990: Distribution and activity of bacterioplankton in the marginal ice zone of the Weddell-Scotia Sea during austral spring. Mar. Ecol. Prog. Ser.. 61, (in press).

Zwally, H.J., J.C. Comiso, C.L. Parkinson, W.J. Campbell, F.D. Darsey and P. Gloersen, 1983a: Antarctic Sea Ice, 19731976: Satellite passive- micronave observations. NASA SP-459. Washington, D.C. 206 pp.

C.L. Parkinson and J.C. Comiso, 1983b: Variability of Antarctic sea ice and changes in carbon dioxide. Science. $220,1005-1012$. 